\title{
Exploring Potential Drivers of Employee Engagement, Enablement, and Empowerment: A Quest Toward Developing a Framework for Building Sustainable Employee Excellence for Manufacturing Environment in Indonesia
}

\author{
Iman Permana \\ Jann Hidajat Tjakraatmadja \\ Dwi Larso \\ Agung Wicaksono
}

School of Business and Management, Bandung Institute of Technology, Indonesia

Email: iman.permana@sbm-itb.ac.id

Doi:10.5901/mjss.2015.v6n2s1p577

\section{Abstract}

Survival and sustainability in today's business dynamics are very much driven by how high-performing the business culture is in an organization. This organizational culture is very much driven by the actions of every person in the organization. These actions, along with the results of the actions, are basically what employee excellence is all about. This paper is a result of a study aimed at developing a framework for sustainable employee excellence through the constructs of engagement, enablement, and empowerment. The study commenced with literature review to identify potential drivers of each of these constructs, which were then used in conceptual theory building to come up with the proposed framework. To further explore and confirm these drivers, the study then proceeded with considerable number of evidence-based interviews with several layers of employees in several manufacturing organizations in Indonesia, both national and multinational companies. Upon developing the proposed framework, this paper also provided propositions and explored directions for future research.

Keywords: engagement; enablement; empowerment; employee Excellence;

\section{Introduction}

The global economy is now becoming more and more dynamics. The marketplace is becoming more and more competitive. Change is inevitable. Organizations must adapt quickly to changes so they can turn challenges into commercial opportunities. This is critical to both survival and success. In this context, organizations require people who are committed to their roles and responsibilities, who are capable of performing their tasks and challenges, and who are capable of being empowered to independently solve problems and make decisions promptly.

Peter Senge (1990), in his best-seller "The Fifth Discipline", argued that the organizations that would excel in the future would be those that discover how to tap people's commitment and capacity at all levels of the organizations. This argument holds true even until now, as Toyota showed throughout its 30-year tenure of excellence. The secret, as disclosed by Liker and Meier (2007) in their book "Toyota Talent", is people. They argue that it is the knowledge and capability of people that distinguish a company from another.

A study by Hay Group unveiled that companies with consistent focus on employee engagement thrived through the 2001/2002's downturn and gained improved motivation and loyalty. Werhane and Royal (2009) in their cross-industry analysis with more than 400 companies across the globe discovered that the organizations that scored highest (top quartile) in employee engagement demonstrated 2.5 times higher revenue growth than that of those who scored the lowest (bottom quartile). Retaining engaged and capable people is, therefore, of utmost importance to an organization's success and competitive edge.

Is engagement alone enough? Notwithstanding the significance of employee engagement, a more profound question arises: why do many companies that enjoy high level of employee engagement still struggle with their performance? We argue that employee engagement alone does not guarantee employee excellence. Hay Group (2010) reported that organizations that engaged and enabled employees reduced voluntary turnover by $54 \%$. A study of ten global companies by Towers-Watson (2011), using employee surveys with measures of engagement and enablement, 
showed that companies with high level of both measures enjoyed the highest level of net profit margin. Clearly, it shows that engagement alone is not enough.

Furthermore, literature study also found that how an employee performs correlated with her/his capabilities of problem solving and decision making (Conger \& Kanungo, 1988). These capabilities are associated with employee empowerment. It is about the extent to which an employee feels she/he has the authority to make decisions andinstead of waiting for orders or instructions-to take responsibility for using the organization's resources to achieve results (Osborne \& Plastrik, 2000).

\subsection{Purpose}

Previous studies found in literature review explored engagement alone, or engagement and enablement, or empowerment alone, in relation with employee excellence. No previous study could be found that assessed all these three constructs altogether with regard to employee excellence. Mapping of the literature review suggested that these three constructs are indeed distinct constructs. Engagement is about commitment and efforts. Enablement is about provision of work necessities and environment. Empowerment is about authority and responsibility. This paper proposes that in order for employee excellence to be sustainable, it must come from the three constructs altogether. Therefore, the big question that this paper strives for answers is "what are the drivers if we want to engage, enable, and empower our employees?" Hence, the research was carried out with the objective of identifying the drivers of employee engagement, enablement, and empowerment, in an effort to develop a framework for sustainable employee excellence for manufacturing environment in Indonesia.

\section{Methodology}

In our quest to seek for answers to the above research question, we commenced the study by reviewing literature on relevant topics of engagement, enablement, and empowerment. Findings from literature review were then mapped to identify research gap and to seek for potential drivers of engagement, enablement, and empowerment. Following literature reviews, a qualitative research through evidence-based interviews in several manufacturing organizations in Indonesia was conducted to further explore and confirm the findings from the literature review.

\subsection{Literature review on engagement}

Numerous academic researches have been published on employee engagement over the past decade. Definitions of engagement offered by practitioners and in academic publications vary widely. "Much of what has been written about employee engagement comes from the practitioner literature and consulting firms. There is a surprising dearth of research on employee engagement in the academic literature" (Saks, 2006). Kahn (1990), one of the first to theorize about work-related engagement, described engaged employees as being fully physically, cognitively, and emotionally connected with their work roles. More recently, Macey, Schneider, Barbera, and Young (2009) defined employee engagement as 'an individual's sense of purpose and focused energy, evident to others in the display of personal initiative, adaptability, effort, and persistence directed toward organizational goals.' It shows the extent to which an employee is motivated to contribute to organizational success and is willing to apply discretionary effort to accomplishing tasks that are important to the achievement of organizational goals (Wiley, Kowske, \& Herman, 2010). Engagement is all about obtaining the right level of passion from people. An engaged employee is excited about her/his works because, as Seijts and Crim (2006) stated, an engaged employee is willing to invest discretionary effort beyond normal duty. An engaged employee is not just committed. She/he is not just passionate or proud. She/he has a clear picture on her/his own future in the organization.

Further literature review revealed that employee engagement related to how people perceive their tangible rewards (Harter, Schmidt, \& Keyes, 2002a; Wilson, 2007; Binhu, 2012). Newman, Joseph, and Hulin (2010) showed engagement construct that underlay job satisfaction. Shahnawaz and Jafri (2009) explored how psychological capital as introduced by Luthans, Yousseff, and Avolio (2007) had some role in influencing employee engagement through organizational commitment. They defined psychological capital as an individual's positive psychological state of development, which is characterized by having confidence (self-efficacy) to take on and put in the necessary effort to succeed at challenging tasks, making a positive attribution (optimism) about succeeding now and in the future, persevering toward goals and, when necessary, redirecting paths to goals (hope) in order to succeed, and when beset by problems and adversity, sustaining and bouncing back (resilience) to attain success. 
Fleck and Inceoglu (2010) offered a model of engagement, in which the organizational engagement was regarded as 'alignment', i.e. employees' view of the organization's direction was aligned with the direction being taken by the organization. They argued that job-fit and organization-fit drove engagement. Densten (2005), Wilson (2007), Nicholson (2009) reported that the work that gave a feeling of personal accomplishment, opportunities for growth and development, and confidence and trust in leadership played roles in emanating employee engagement. Schaufeli, Bakker, and Salanova (2006) found that engagement and age were so weakly related that it could hardly be considered meaningful. They also found that no systematic gender differences were observed.

Synthesizing the various definitions and models of engagement found in the literature review, we propose the definition of employee engagement as 'the intensity of employees' emotional connection (i.e. attachment) that they feel for their organization, which influences them to exert greater discretionary effort (i.e. extra effort) committed to achieving their work goals." Thus, in view of this definition, engagement consists of two components: affective attachment to (and intention to remain with) an organization and discretionary effort (i.e. willingness) to go above and beyond formal job requirements. Derived from this definition and findings from the literature review, we identified and propose the following potential drivers of engagement (listed not in rank of importance):

Table 1. List of potential drivers of engagement

\begin{tabular}{|c|c|c|}
\hline Potential drivers & Definition & Reference \\
\hline $\mathrm{X}_{1}$, vision & The extent to which an employee is confident with her/his future in the organization. & Seijts et al. (2006) \\
\hline $\mathrm{X}_{2}$, passion & $\begin{array}{l}\text { The extent to which an employee is motivated to contribute to organizational success by } \\
\text { willingly applying discretionary efforts to accomplishing tasks important to achieving } \\
\text { organizational goals. }\end{array}$ & $\begin{array}{l}\text { Robinson et al. } \\
\text { (2003), Wiley et } \\
\text { al. (2010) }\end{array}$ \\
\hline $\begin{array}{l}\mathrm{X}_{3} \text {, reward/ } \\
\text { recognition }\end{array}$ & $\begin{array}{l}\text { How an employee perceives her/his reward for certain work outcome, that is the } \\
\text { recognition she/he receives from her/his superior for the performance she/he has } \\
\text { contributed to her/his work. }\end{array}$ & $\begin{array}{l}\text { Harter et al. } \\
(2002), \text { Wilson } \\
(2007)\end{array}$ \\
\hline $\mathrm{X}_{4}$, job satisfaction & $\begin{array}{l}\text { Personal satisfaction resulting from individuals' contribution to the company's success, } \\
\text { which represents an alignment of maximum job satisfaction with maximum job } \\
\text { contribution. }\end{array}$ & $\begin{array}{l}\text { BlessingWhite } \\
\text { (2011) }\end{array}$ \\
\hline $\begin{array}{l}X_{5} \text {, alignment of } \\
\text { value and interest }\end{array}$ & $\begin{array}{l}\text { The extent to which an employee sees a mutuality of interest between her/his values } \\
\text { and aspirations and those of the organization. }\end{array}$ & Wilson (2007) \\
\hline $\begin{array}{l}\mathrm{X}_{6} \text {, work } \\
\text { accomplishment }\end{array}$ & $\begin{array}{l}\text { The extent to which the work itself gives an employee a feeling of personal } \\
\text { accomplishment. }\end{array}$ & $\begin{array}{l}\text { Wilson (2007), } \\
\text { Nicholson (2009) }\end{array}$ \\
\hline $\begin{array}{l}\mathrm{X}_{7} \text {, opportunity for } \\
\text { personal growth }\end{array}$ & $\begin{array}{l}\text { The extent to which an employee believes that she/he has opportunities for growth and } \\
\text { development in the organization. }\end{array}$ & Wilson (2007) \\
\hline $\begin{array}{l}\mathrm{X}_{8} \text {, trust in } \\
\text { leadership }\end{array}$ & $\begin{array}{l}\text { How an employee perceives that the values of the organization are evident in senior } \\
\text { management's actions. }\end{array}$ & $\begin{array}{l}\text { Densten (2005), } \\
\text { Wilson (2007) }\end{array}$ \\
\hline $\begin{array}{l}X_{9}, \text { psychological } \\
\text { capital }\end{array}$ & $\begin{array}{l}\text { Positive psychological state of development of an employee, which is characterized by } \\
\text { having confidence (self-efficacy) to take on and put in the necessary effort to succeed at } \\
\text { challenging tasks, making a positive attribution (optimism) about succeeding now and in } \\
\text { the future, persevering toward goals, redirecting paths to goals (hope) when necessary } \\
\text { in order to succeed, and sustaining and bouncing back (resilience) when beset by } \\
\text { problems and adversity. }\end{array}$ & $\begin{array}{l}\text { Shahnawaz et al. } \\
\text { (2009) }\end{array}$ \\
\hline $\begin{array}{l}X_{10} \text {, person's fit } \\
\text { with job }\end{array}$ & $\begin{array}{l}\text { The extent to which an employee is 'absorbed' in her/his work resulting in a sense of } \\
\text { engrossment when doing the work and how much 'energy' she/he draws from such } \\
\text { work. }\end{array}$ & Fleck et al. (2010) \\
\hline $\begin{array}{l}\mathrm{X}_{11} \text {, person's fit } \\
\text { with organization }\end{array}$ & $\begin{array}{l}\text { The extent to which an employee's views of the organization's direction are aligned with } \\
\text { the direction being taken by the organization and how much she/he 'identifies' } \\
\text { herself/himself as part of the organization. }\end{array}$ & Fleck et al. (2010) \\
\hline
\end{tabular}

\subsection{Literature review on enablement}

Organizations often face fluctuating economic trends and changes in business operations, staffing models, leadership, etc. These changes can cause employees to be ineffective although they are engaged. Organizations shall remove barriers that hamper employees from being effective. For employees to be able to surmount obstacles successfully, employers must ensure employees are optimally enabled. This is where employee enablement comes into play.

Employee enablement was first conceptualized by Adler and Borys (1996) when they proposed workflow formalization to contrast two types of bureaucracy. No conceptual correlations or causal relationships were disclosed in their study. Ever since this work by Adler and Borys, employee enablement has been considered a relatively rare subject of research in the existing stream, and therefore, researches related to the construct of enablement are still few. 
Nevertheless, some studies, such as Hay Group (2010) and Towers-Watson (2011), suggested the increasingly important roles of enablement, along with engagement, to the organizational performance. A study by the Economist Intelligence Unit showed a positive correlation between employees' degree of enablement and self-reported financial performance (Wright, 2008). The study demonstrated the positive association between enablement, profitability, revenue growth, tangible assets, and strategic success. Although it is not possible to say that enablement causes superior performance, there is a clear correlation between an organization's ultimate performance and the degree to which the organization attempts to give its people what they need to do their jobs well. This attempt can be displayed in how the organization designs jobs. Enablement is all about having the right people with the right skills for the right job, which will expectedly allow people to carry out their tasks optimally. Enabled people are both ready and able to do their jobs.

According to Wright (2008), enablement is important to employees' sense of pride and confidence in their work. He argued that management had to provide infrastructure for sharing data to help employees understand the context of their work and carry out operational actions. An enabling work environment is defined as one that provides the tools and processes to deal with employee frustrations (Colenbaugh \& Reigel, 2010). Towers-Watson report (2011:2) stated that "enablement means that organization must provide, at minimum, well-functioning equipment, the necessary supplies, effective work processes, and clear direction from supervisors." All of these provisions contribute to employees' ability to get the job done. Hence, we argue that enablement means providing organizational and informational conditions that allow employees to perform optimally. These provisions include tools (to do the job the best possible), financial resources (that may be needed to buy these tools and to allow for enough people to handle the workload), a collaborative working environment (that motivates people and reduces the cost of working together), and clarity of policies and procedures.

Combining the definition of employee enablement as offered by the Economist Intelligence Unit (Wright, 2008) with that of Hay Group (Collenbaugh et al., 2010), this paper proposes the definition of employee enablement as "the extent to which employees feel they are provided with what they need to do their jobs well and are provided with an environment in which they feel comfortable to perform to the best they can be". Thus, in view of this definition and the definition of employee engagement presented earlier, we argue that employees can be engaged while they may not be necessarily enabled. This, then, suggests that the two constructs are distinct. Based on the above definition and findings from the literature review, we identified and propose the following drivers of enablement (listed not in rank of importance):

Table 2. List of potential drivers of enablement

\begin{tabular}{|c|c|c|}
\hline Potential drivers & Definition & Reference \\
\hline $\begin{array}{l}Y_{1}, \text { adequacy of work } \\
\text { equipment and } \\
\text { supplies }\end{array}$ & $\begin{array}{l}\text { The extent to which an employee perceives how adequately the organization } \\
\text { provides well-functioning equipment and the necessary supplies of work materials, } \\
\text { which play significant roles in how well the employee gets the job done. }\end{array}$ & Towers-Watson (2011) \\
\hline $\mathrm{Y}_{2}$, clear direction & $\begin{array}{l}\text { The extent to which an employee is aware of and understands the direction that the } \\
\text { organization provides and communicates to employees to enable them to carry out } \\
\text { the tasks in their job. }\end{array}$ & $\begin{array}{l}\text { Collenbaugh et al. } \\
\text { (2010), Towers-Watson } \\
\text { (2011) }\end{array}$ \\
\hline $\begin{array}{l}Y_{3} \text {, effective work } \\
\text { processes }\end{array}$ & $\begin{array}{l}\text { The extent to which an employee perceives that the organization provides effective } \\
\text { work processes, which contribute to her/his ability to get jobs done. }\end{array}$ & Towers-Watson (2011) \\
\hline $\begin{array}{l}\mathrm{Y}_{4} \text {, supportive working } \\
\text { environment }\end{array}$ & $\begin{array}{l}\text { How an employee perceives how collaborative is the organization's working } \\
\text { environment with regards to motivating people and reducing the cost of working } \\
\text { together in such an extent that it allures enough people to handle the workload. }\end{array}$ & $\begin{array}{l}\text { Choo et al. (2010), } \\
\text { Towers-Watson (2011) }\end{array}$ \\
\hline$Y_{5}$, job design & $\begin{array}{l}\text { The extent to which an employee is aware of and understand that the organization } \\
\text { attempts to give the right position to the right people (i.e. how the organization } \\
\text { designs jobs), which will expectedly allow people to carry out their tasks optimally. }\end{array}$ & Wright (2008) \\
\hline $\begin{array}{l}Y_{6} \text {, infrastructure for } \\
\text { data sharing }\end{array}$ & $\begin{array}{l}\text { The extent to which an employee is aware of and understands that the organization } \\
\text { provides infrastructure for sharing data that help employees to understand the } \\
\text { context of their work and to carry out operational actions. }\end{array}$ & Wright (2008) \\
\hline $\begin{array}{l}Y_{7} \text {, opportunity for } \\
\text { learning and sharing }\end{array}$ & $\begin{array}{l}\text { The extent to which an employee believes that the organization provides means for } \\
\text { her/him to learn and share knowledge with others, which enhances her/his } \\
\text { capability to perform her/his work. }\end{array}$ & $\begin{array}{l}\text { Wright (2008), Choo et } \\
\text { al. (2010) }\end{array}$ \\
\hline
\end{tabular}

\subsection{Literature review on empowerment}

Employees will not be able to execute actions for greater results when and if they do not have the authority to make decisions. It is crucial to ensure that employees who are committed to their roles and responsibilities (i.e. engaged) and who are at the right position with the right resources and environment (i.e. enabled) are provided with the proper level of 
authority of decision making (i.e. empowered). Employee empowerment is about the authority to make decisions (Osborne at al., 2000). Spreitzer (1995) argued that empowerment referred to individual sense that they 'have a choice in initiating and regulating actions.' Empowerment is 'the degree to which an individual can influence strategic, administrative or operating outcomes at work.'

In this context, empowerment translates into how much employees are informed and are involved in decisions that affect their work and the work of their organization. When and if these conditions of being informed and being involved are in place, empowerment can improve employees' sense of competence and confidence in their ability to accomplish their work. They feel they are given the opportunity to express their concerns and to make suggestions for improvements. Hence, empowerment may not exist when an employee's superior is disinclined to entrust some of her/his decision-making authorities to her/his subordinates. It may not succeed when employees' roles and responsibilities are not clear.

Building on the above premises, we argue that empowerment may not live well in an authoritarian style of management. Unlike the authoritarian style, transformational leadership is found to closely correlate with the feeling of empowerment (Avey, Hughes, Norman, \& Luthans, 2007). Transformational leadership has four important features (Avolio, Bass, and Jung, 1999): (1) intellectual stimulation (i.e. stimulating followers' creativity and innovativity), (2) individualized consideration (i.e. creating a supportive atmosphere for followers to overcome personal challenges), inspirational motivation (i.e. inspiring followers by sharing the vision and encouraging excellent performance), and idealized influence behavior (i.e. leader's role modeling in the workplace). According to Ismail, Mohamed, Sulaiman, Mohamad, and Yusuf (2011), transformational leadership related to empowerment and that this relationship positively and significantly correlated with organizational commitment.

Avey et al. (2007) revealed that empowerment also related to positive psychological capital. In explaining how the factors of psychological capital interact, Luthans et al. (2007) exemplified that a hopeful person possesses 'the will and the way' to achieve her/his goals, and thus, is more motivated to and capable of overcoming adversities, i.e. more resilient. A confident person is able to transfer and apply her/his hope, optimism, and resiliency to the specific tasks within specific domains of their lives. A resilient person is adept in utilizing the adaptational mechanisms necessary for realistic and flexible optimism. Self-efficacy, hope, and resiliency can in turn contribute to an optimistic explanatory style through internalized perceptions of being in control, of being empowered.

Based on the above discussions of literature finding on empowerment, this paper proposes the definition of employee empowerment as "the extent to which employees feel they are given problem-solving and decision-making authority to take responsibility for using the organization's resources to achieve results." Derived from this definition and findings from the literature review, we identified and propose the following drivers of empowerment (listed not in rank of importance):

Table 3. List of potential drivers of empowerment

\begin{tabular}{lll}
\hline Potential drivers & Definition & Reference \\
\hline $\begin{array}{l}Z_{1} \text {, superior's } \\
\text { willingness to delegate }\end{array}$ & $\begin{array}{l}\text { The extent to which an employee believes that her/his superior is inclined to entrust some of } \\
\text { the superior's decision-making authorities to her/him such that she/he can perform optimally } \\
\text { without having to wait for the superior's concurrence. }\end{array}$ & Spreitzer (1995) \\
$\begin{array}{l}Z_{2}, \text { clear roles and } \\
\text { responsibility }\end{array}$ & $\begin{array}{l}\text { How clear are the roles and responsibilities to an employee with regards to her/his work, } \\
\text { which help her/him perform optimally. }\end{array}$ & Spreitzer (1995) \\
$\begin{array}{l}Z_{3}, \text { transformational } \\
\text { leadership }\end{array}$ & $\begin{array}{l}\text { The extent to which an employee perceives how the state of intellectual stimulation, } \\
\text { individualized consideration, inspirational motivation, and individualized influence behaviour }\end{array}$ & $\begin{array}{c}\text { Avey et al. (2007), } \\
\text { Ismail et al. (2011) }\end{array}$ \\
$\begin{array}{llll}Z_{4,} \text { psychological } \\
\text { capital }\end{array}$ & $\begin{array}{l}\text { The degree to which an employee possesses the four positive-organizational-behaviour } \\
\text { capacities of self-efficacy (confidence), hope, optimism, and resiliency, which contribute to an } \\
\text { optimistic explanatory style through internalized perceptions of being in control. }\end{array}$ & Avey et al. (2007) \\
\hline
\end{tabular}

As a summary, a mapping of the literature review is presented in Figure 1. This map indicates the research position of this study (marked in dark grey boxes and dashed arrow lines) among the existing theories and models as explained previously. This is the base of the framework that this paper proposes. 


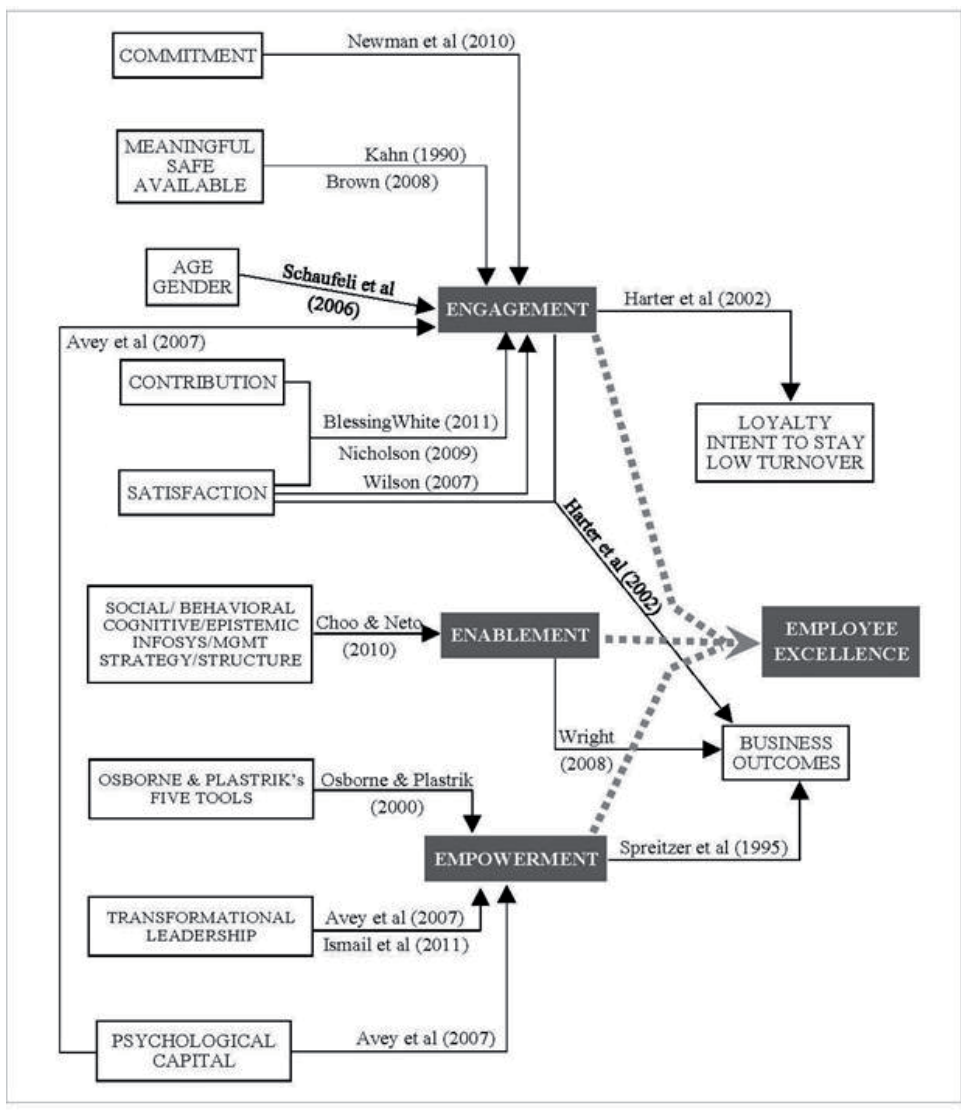

Figure 1. Literature review mapping

\subsection{Evidence-based interview}

To further explore and qualitatively confirm the potential drivers identified from the literature study, we carried out evidence-based interviews. This kind of interview focuses on specific evidence as to how the respondents confirm the potential drivers being explored. It includes such questions as "Tell me about the time when you have...", "Describe an example of...", and "Tell us about an occasion when you had to..." This interview technique can be expected to improve objectivity of opinions (Kvale, 1996).

Manufacturing companies were chosen for this study due to their massive work force and their largest share of foreign direct investment inflows into Indonesia (OECD Report, 2012), and thus, the study would add values to the Indonesian business sector by focusing on manufacturing organizations. Adler and Borys (1996) indicated that the critical importance of employee enablement was particularly visible in repetitive operations such as in manufacturing assembly.

Eight manufacturing companies were selected for this study. Four companies are foreign direct investment multinational consumer goods companies, while the other four are local or national companies. These are companies in the business of fashion dolls, garments, electronics, packaging, and food industries. Employee populations range from a few hundred to several thousand people. Local or national companies were researched for their local practices that might contribute to the proposed framework. Multinational companies were chosen on the basis of their multinational nature of operation to address multicultural issue in manufacturing environment.

The main respondents were chosen from the employee level that interacts intensively with the labor force and serves a critical role as the connecting bridge between management strategy and implementation at the shop floor. These are the manufacturing production foremen. The subject companies have foremen ranging from 12 people to 110 people. There were a total of 257 foreman researched in this study, which represented $53 \%$ of the total foremen in the eight subject companies. To obtain broader view on the subject matter, we also included samples from the foremen's direct subordinates, direct superiors, and their managers. These respondents were selected based on their potential 
contribution to the proposed framework and the demand of the research objectives. For this reason, we selected the respondents based on purposive sampling (or judgmental sampling) to ensure people being interviewed are those with knowledge on subject matters. In a period of about one year from mid-2013 until mid-2104, a total of 257 foremen, 257 direct subordinates of the foremen, 83 direct superiors of the foremen, and 34 managers were taken as the subjects of the interviews. Due to large numbers of interviewees, one person in each subject company helped as an assistant researcher in conducting the interviews based on a predetermined checklist of questions and answers, after being trained and supervised during the initial sessions. Follow-up interviews on random samples were also conducted to clarify certain items.

In search of what drives employee engagement, enablement, and empowerment, we explored the potential drivers through key words found during the interviews. Findings related to identifying the potential drivers were categorized as: type 1 respondents (i.e. they gave evidence of existence of potential driver with examples from own experience or from what others told or what they heard from others), type 2 respondents (i.e. they indicated existence (opinion only) of potential driver but could not provide example as evidence), and type 3 respondents (i.e. no driver or evidence was indicated). The results are shown in Figure 2, with type 1 in grey bar, type 2 in white bar, and type 3 in black bar. Numbers in the bars indicated how many respondents in each type. For the definitions of X's, Y's, and Z's, please see Tables 1-3.

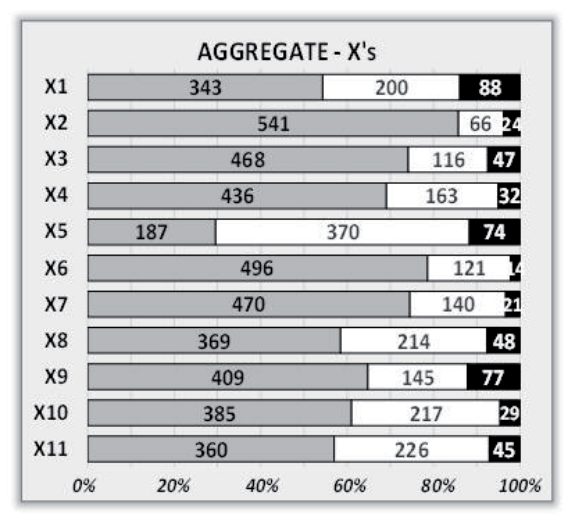

Figure 2. Evidence-based interview result for potential drivers of engagement
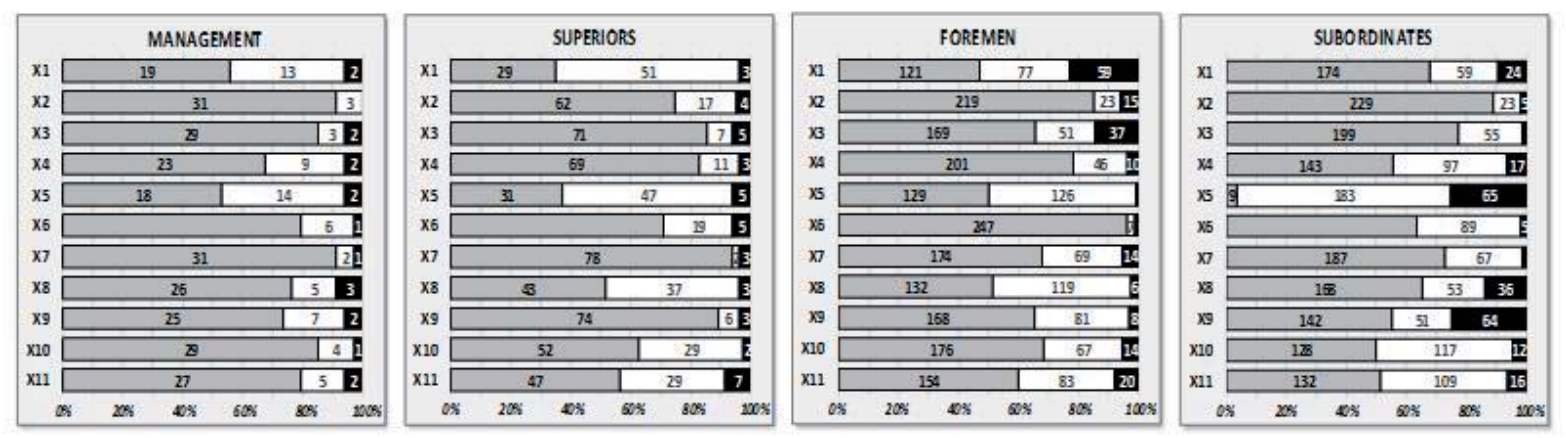

Figure 3. Evidence-based interview results for key words of engagement decomposed based on job level categories of respondents

Most respondents, especially the labor force (those in the subordinate level), responded most favorably with evidence of 'passion' by providing examples of how they apply discretionary efforts to accomplishing tasks. On the other hand, the respondents appeared to respond least favorably with evidence of 'alignment of value and interest.' Only a handful of the labor force could provide evidence of how they see a mutuality of interest between their value and aspiration and those of the organization. Follow-up interviews indicated that these employees felt that they were not provided with adequate guidance from the foremen on how to see this alignment and how to act on it.

Interestingly, the data shows that more percentage of employees at the subordinate level (i.e. the labor force) than 
employees at other levels could provide evidence of how they were confident with their future in the companies. Findings from follow-up interviews suggested that how long of a horizon of company's future an employee could see would determine how the employee saw her/his future in the company. Paradoxically, short-sightedness apparently could result in perceived confidence with the future.

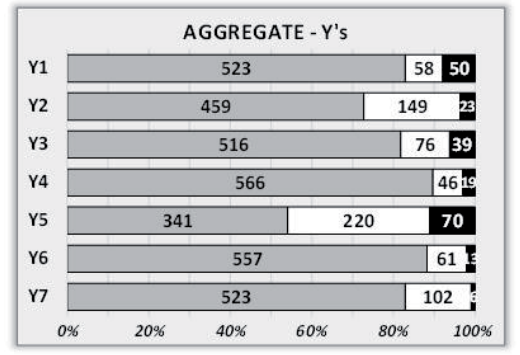

Figure 4. Evidence-based interview result for potential drivers of enablement
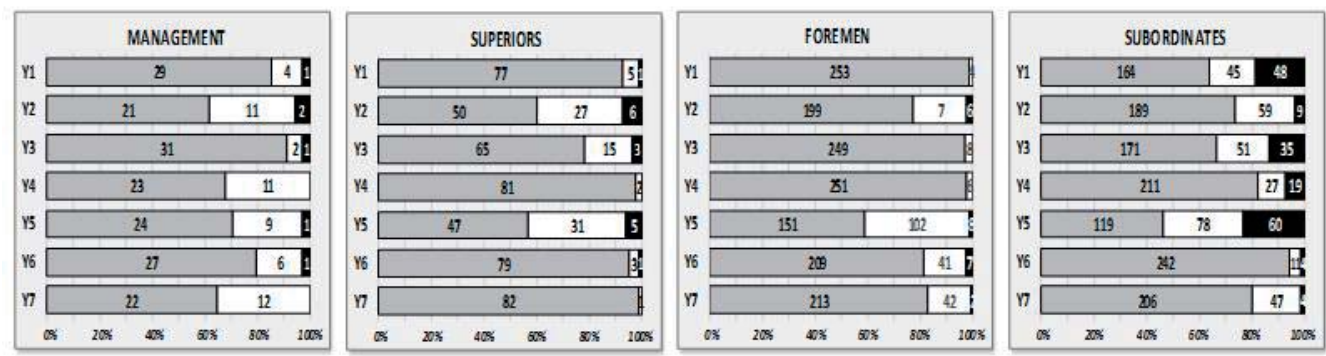

Figure 5. Evidence-based interview results for key words of enablement decomposed based on job level categories of respondents

'Supportive working environment' and 'infrastructure for data sharing' were two drivers where most respondents could provide evidence of how they became enabled in their daily job. The others driver were also relatively high in the number of respondents that could provide evidence. Across all levels of respondents, except management, one driver (Y5) seemed to be low, which may suggest that the respondents had a low understanding and awareness of how their organization attempted to give the right positions to the right people. Human Resources department could play roles in communicating how the organization designs jobs.

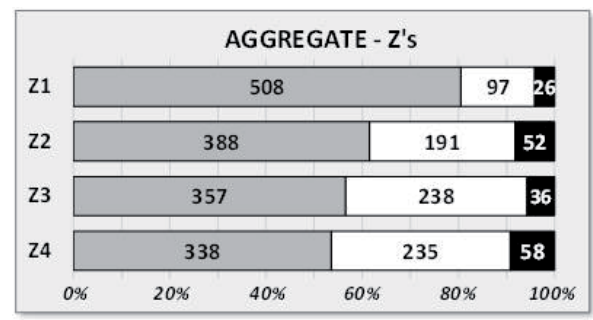

Figure 6. Evidence-based interview result for potential drivers of empowerment
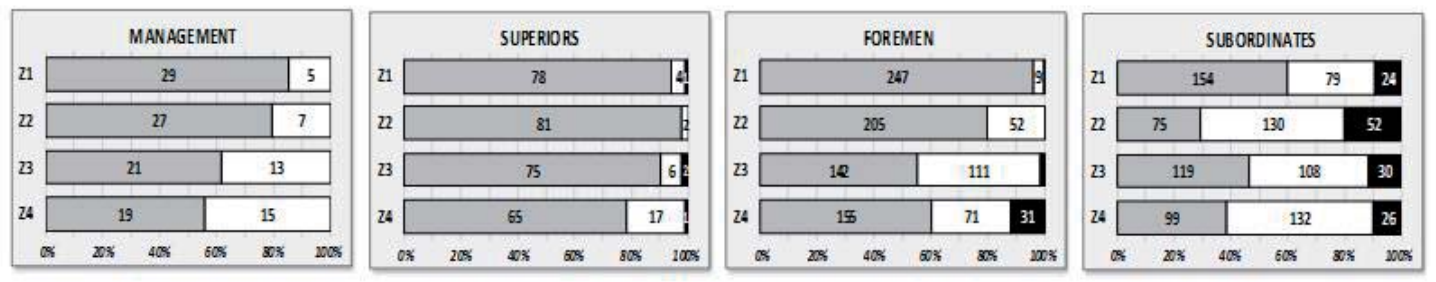

Figure 7. Evidence-based interview results for key words of empowerment decomposed based on job level categories of respondents 
Relatively highest percentages of the number of respondents that could provide evidence of when they felt empowered were observed in 'superior's willingness to delegate.' The other drivers of empowerment were also relatively high in percentage. 'Clarity of roles and responsibilities' seemed to be low in the labor force, while it was relatively high in the foremen level. Follow-up interviews indicated the need of more effort from the foremen to cascade employees' roles and responsibilities down to the labor force.

Evidence-based interviews with management, superiors of the foremen, the foremen themselves, and their subordinates conducted in the eight subject companies showed that all potential drivers identified in literature review were confirmed with adequately presented evidences at varying degrees. No other potential drivers were identified during the interviews. Decomposing the respondents' job level categories suggested that the higher the level, the more evidences of the drivers they could unveil in the interviews. Drivers X5 (alignment of value and interest) and Y5 (job design) appeared to be noticeably smaller in quantity of type 1 respondents than the other drivers. This calls for further analysis in future study to examine their importance toward the constructs.

\section{Proposed Framework and Propositions}

Three different constructs (engagement, enablement, and empowerment) were explored in this study. This study explored what are behind each of the constructs, what are needed in and for each of the constructs, what drives each of the constructs. Developed based on the literature review, and then confirmed through evidence-based interviews, a framework is proposed on sustainable excellence of employees built through these three constructs. The main idea is basically about ensuring that motivated employees, who are highly engaged (i.e. engagement), are at the right position with right resources (i.e. enablement), and with the right level of authority of decision making (i.e. empowerment).

We argue that engagement is about what is in one's heart (i.e. willingness), enablement is about what is provided in the surrounding, and empowerment is about what is entrusted to one's capability. Hence, an employee can be engaged while he/she may not be necessarily enabled and/or empowered, or vice versa. Employees who are empowered and enabled, but lack of commitment and efforts, can become disengaged stars. Employees who are engaged and enabled, but are not adequately authorized to take responsibility, are just like powerless stars. Employees who are empowered and engaged, but are not provided with what they need for their job, will become disabled stars. Thus, we argue that these constructs are distinct, and therefore, it is important to test these constructs together as a furtherance of this study.

Conceptually, the framework is modeled as shown in Figure 3, with the potential drivers listed alphabetically, not in the rank of importance.

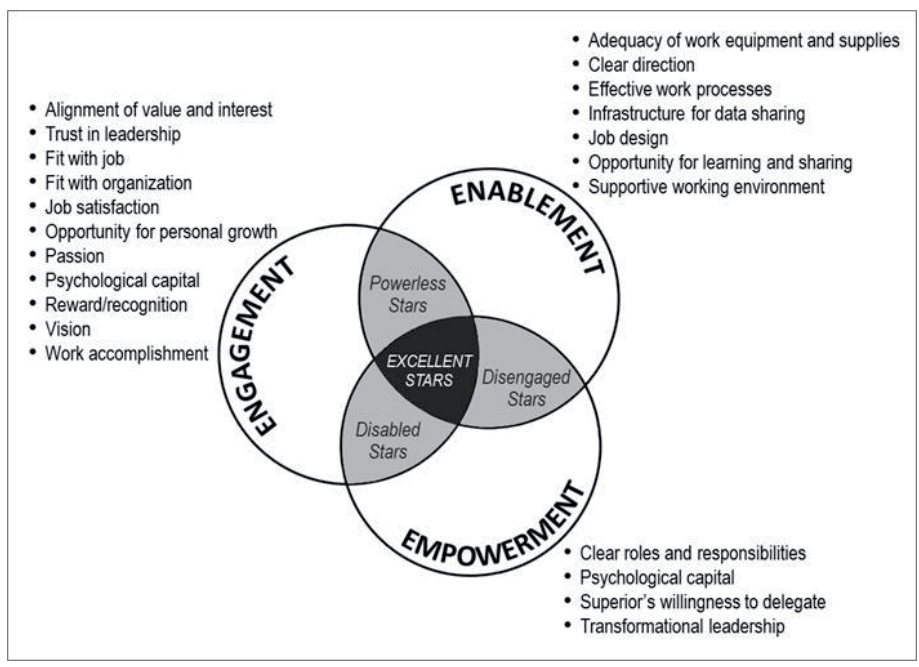

Figure 8. Proposed framework of sustainable employee excellence

Within the context of our framework, we argue that these drivers account for varying degrees of importance toward the constructs. This is to say that, for instance, some engagement drivers are more important than others in influencing employee engagement. The same argument also applies to enablement and empowerment. On the account of exploring 
the most important drivers in predicting employee engagement, enablement, and empowerment, these arguments lead to the following propositions:

P1: Among a set of potential drivers of employee engagement that were identified through the literature review, there is a key driver that is the most important for predicting employee engagement.

P2: Among a set of potential drivers of employee enablement that were identified through the literature review, there is a key driver that is the most important for predicting employee enablement.

P3: Among a set of potential drivers of employee empowerment that were identified through literature review, there is a key driver that is the most important for predicting employee empowerment.

\section{Conclusions and Recommendations}

This study provided a new approach in understanding how to engage, enable, and empower employee, especially the foremen level in manufacturing organizations, in order to develop their excellence. The research has identified important drivers to be included in the constructs of employee engagement, enablement, and empowerment. The theory development of the proposed framework is a key contribution of this research. It is expected to provide a new approach in understanding the antecedents of employee engagement, enablement, and empowerment, which in turn can shed light on the understanding of how to pave the way for developing employees. Knowing the drivers will help organizations to formulate what needs to be done to engage, to enable, and to empower employees. By understanding what drives their engagement, enablement, and empowerment, businesses can apply the knowledge to help nurturing their employees.

This paper, however, has not addressed the questions of which drivers are more important than the others, whether or not there are links between them, and how employee excellence correlates with employee engagement, enablement, and empowerment. The understanding of this framework will even be much better when all the three constructs are further examined for answers to the above questions. Future research should therefore be directed around these questions. It may also include exploration on how to grow the drivers in order to further the development of employee excellence.

Manufacturing organizations were the focus of this study. With this focus, further use of the results of the study should be applied with care, for they may not be generalizable to other types of organizations. This gap may suggest topics for future research to deep dive the extent of the applicability of the framework. Therefore, a recommendation for future research to fill in the gap would be to reproduce this study in different types of organizations or industries, or even countries, to investigate the influence of cross-border cultural differences. These additional future researches can be expected to provide a much better roadmap to building employee excellence, which in turn, will bring about business excellence of the organizations.

\section{References}

Adler, Paul S. \& Borys, Bryan (1996). Two types of bureaucracy: Enabling and coercive. Administrative Science Quarterly, 41(1), 61-89.

Avey, J.B., Hughes, L.W., Norman, S.M., \& Luthans, K.W. (2007). The role of positive capacities, transformational leadership, and empowerment in combating employee negativity. Working Paper.

Avolio, B.J., Bass, B. \& Jung, D. (1999). Re-examining the components of transformational and transaction using the multi-factor leadership questionnaire. Journal of Occupational and Organizational Psychology, 72, 441-462.

BlessingWhite Report (2011). Employee Engagement Report 2011. Princeton, New Jersey.

Binhu, P. H. (2012). Role of job related factors in engaging employees. Sumedha Journal of Management, 1(3), 56-68.

Choo, C.W. \& Neto, R.C.D.A. (2010). Beyond the "ba": Managing enabling contexts in knowledge organizations. Journal of Knowledge Management, 14(4), 592-610.

Colenbaugh, R. \& Reigel, B. (2010). Enabling, engaging, and rewarding employees. A Study of World-at-Work Reward Professionals, HayGroup.

Conger, J. \& Kanungo, R. (1988). The empowerment process: Integrating theory and practice. Academy of Management Review, 13, 471-482.

Densten, I.L. (2005). The relationship between visioning behaviours of leaders and follower burnout. British Journal of Healthcare Management, 16(2), 105-118.

Fleck, S. \& Inceoglu, I. (2010). A comprehensive framework for understanding and predicting engagement. Handbook of Employee Engagement, 31-42.

Harter, J.K., Schmidt, F.L., \& Keyes, C.L. (2002a). Well-being in the workplace and its relationship to business outcomes: A review of the Gallup studies. In C.L. Keyes \& Haidt, J. (Eds.), Flourishing: the Positive Person and the Good Life, 205-224. Washington, D.C. : American Psychological Association.

Harter, J.K., Schmidt, F.L., \& Hayes, T.L. (2002b). Business-unit-level relationship between employee satisfaction, employee 
engagement, and business outcomes: A meta-analysis. Journal of Applied Psychology, 87(2), 268-79.

Hay Group Report (2010). Hay Study Report 2010 on Employee Opinion Survey.

Ismail, A., Mohamed, H.A., Sulaiman, A.Z., Mohamad, M.H., \& Yusuf, M.H. (2011). An empirical study of the relationship between transformational leadership, empowerment, and organizational commitment. Business \& Economics Research Journal, 2(1), 89107.

Kahn, W.A. (1990). Psychological conditions of personal engagement and disengagement at work. Academy of Management Journal, 33(4), 692-724.

Kvale, Steinar (1996). Interviews: An Introduction to Qualitative Research Interviewing. Sage Publications.

Luthans, F., Yousseff, C.M., \& Avolio, B.J. (2007). Psychological Capital: Developing the Human Competitive Edge. Oxford: Oxford University Press.

Macey, W.H., Schneider, B., Barbera, K.M., \& Young, S.A. 2009. Employee Engagement: Tools for Analysis, Practice, and Competitive Advantage. Malden, MA: Wiley.

Newman, D.A., Joseph D.L., \& Hulin, C.L. (2010). Job attitudes \& employee engagement: Considering the attitude 'A-factor'. Handbook of Employee Engagement, 43-61.

Nicholson, N. (2009). Make engagement personal. Communication World, 26(2): 2.

OECD Report (2012). OECD Economic Surveys: Indonesia 2012. OECD Publishing. doi: 10.1787/eco_surveys-idn-2012-en

Osborne, D. \& Plastrik, P. (2000). Employee empowerment: Giving frontline employees the power to improve results. The Reinventor's Fieldbook, 103-142.

Robinson, D. \& Hayday, S. (2003). Employee engagement. In Brief, 129.

Saks, A.M. (2006). Antecedents and consequences of employee engagement. Journal of Managerial Psychology, 21, 600-619

Schaufeli, W.B., Bakker, A.B., \& Salanova, M. (2006). The measurement of work engagement with a short questionnaire: A crossnational study. Educational and Psychological Measurement, 66(4), 701-16.

Seijts, G. H. \& Crim, D. (2006). What engages employees the most, or the ten C's of employee engagement. Ivey Business Journal, (March/April 2006), 1-5.

Senge, P.M. (1990). The fifth discipline: The art and practice of the learning organization. London: Random House.

Shahnawaz, M.G. \& Jafri, M.H. (2009). Psychological capital as predictors of organizational commitment and organizational citizenship behavior. Journal of the Indian Academy of Applied Psychology, 35(2), 78-84.

Spreitzer, G.M. (1995). Psychological empowerment in the workplace: Dimensions, measurement and validation. Academy of Management Journal, 38, 1442-1465.

Towers-Watson Report (2011). Perspectives: the power of three.

Werhane, W. \& Royal, M. (2009). Engaging and enabling employees for company success. Workspan The Magazine of WorldatWork, (October 2009), 39-43.

Wiley, J.W., Kowske, B.J., \& Herman, A.E. (2010). Developing and validating a global model of employee engagement. Handbook of Employee Engagement, 351-362.

Wilson, B. (2007). Employee Engagement: What Managers Need to Know? Marsh \& McLennan Companies.

Wright, W. (2008). Ready, willing and enabled: A formula for performance. The Economist Intelligence Unit. 